\title{
The Causes of the Holocaust
}

\section{T I M O T H Y S N Y E R}

\section{The form: Bloodlands as European history}

Not long ago I was discussing before a theatre audience in Philadelphia a performance of 'Our Class', Tadeusz Słobodziański’s remarkable theatrical reinterpretation of Jan Gross's pioneering book Neighbors. It helped so very much that the discussion took place after rather than before the performance! It is a great honour to find my book at the centre of this discussion by colleagues, but it would be great vanity on my part to expect that every reader of this exchange will have first read my book. And yet without some general sense of the argument and substance of Bloodlands, I can hardly explain why the four responses are so different each from the other, what underlying concerns unite them, and how they might be answered. The book is a study of all German and Soviet mass killing policies in the lands between the Black and Baltic Seas from south to north and from Smolensk to Poznan from east to west. It begins from the observation that fourteen million non-combatants were deliberately killed in this zone between I933 and I945, when both Stalin and Hitler were in power. The figure is very high in its own right, and represents the vast majority of Soviet and German killing. The territory can be defined in terms of the number of murdered, or as the place where the Holocaust was perpetrated, or as the zone touched by both German and Soviet power: all three definitions generate the same map of the bloodlands.

The book includes what I hope to be an accessible theoretical account of mass killing. It took five forms. First, Stalin undertook modernisation by way of the selfcolonisation of his Soviet Union, which involved a deliberate starvation campaign in Soviet Ukraine in 1932 and I933. Then the Soviets effected a retreat into terror. In the Great Terror of 1937 and I938, the Soviet leadership identified peasants, the victims of collectivisation, as the primary threat to Soviet power. In 1939, the Soviets and the Germans invaded Poland together, and carried out a policy of de-Enlightenment. After the Germans broke the alliance and invaded the Soviet Union in June I94I, the two enemies killed civilians in a pattern of belligerent complicity. Hitler envisioned a

Department of History, Yale University, P. O. Box 208324, New Haven CT 06520-8324, USA; timothy.snyder@yale.edu 
racially conceived colonial demodernisation of the Soviet Union and Poland that would take tens of millions of lives, which gave way to a final solution as anti-Semitic goals proved to be more attainable than others. ${ }^{1}$

The bulk of the book is composed of separate accounts, divided by chapter, of individual policies of mass killing: famine in Soviet Ukraine; the peasant and national operations of the Soviet Great Terror; the German and Soviet decapitation of Polish society; German starvation campaigns; the Holocaust in the Baltics, Ukraine, Belarus, and Poland; German 'reprisal' campaigns against civilians. I found it striking that the reviewers seldom engaged with the book on the level where it preeminently operates, that of the description and explanation of each of these individual killing policies. There are vast debates, admittedly not always in English or German, about all of these killing policies; the book participates not just in arguments about the origins of the Holocaust, but in arguments about the origins of Soviet famine and Soviet terror, the meaning of the Molotov-Ribbentrop pact, the relationship of the starvation of Soviet POWs with the Holocaust, and so on. The reviews tend to re-establish the familiar terms and levels of analysis. Perhaps they are right to do so, but I missed an acknowledgement that debates beyond the most familiar might be going on, or that the use of the languages of the region, in secondary as well as primary sources, might enable a useful account of lesser-known policies and experiences which might be significant in and of themselves, and which might recast the familiar debates.

In recent works on the Holocaust we are offered an oscillation between the microand the macro-level, with an occasional dash of (or dash to) the meta-level (theory, or ethics). But surely we cannot understand questions at the micro-level, such as the motivations of collaborations and the experience of victims, without the meso-level, the policies in question as implemented in the time and place? Likewise, we are unable to generate overall macro-level explanations of the killing, or theorise about it, unless we are aware of the general course of each killing policy. We also must be aware of possible relationships between killing policies. Is it not strange, after all, that no book about the Holocaust has ever noted that eight million non-Jews were murdered on the terrains where the Holocaust took place while Hitler was in power? The Holocaust was of course a distinct crime, but if we wish to understand its causes we must attend to the proximate history. If a paramedic were called to a house and found six family members were murdered, he would surely report as much; and if he found eight further corpses from members of other families, he would surely note this as well. Our standard cannot be, must not be, any lower than this.

The possibility of connections among killing policies can only be tested and established at the meso-level, which is where Bloodlands was generally written. ${ }^{2}$ I would not claim that it resolves all of the important questions posed at the

1 These terms appear chiefly in Chapters 4 and 5 - it has mattered more than I might have hoped in reviews that the theoretical and explanatory arguments were in the middle of the book. The entire theoretical argument, using precisely the terms above, is however abstracted on pp. 4I $5-7$.

2 Another meso-level approach, highly successful, has been the regional study. See for example Christian Gerlach, Kalkulierte Morde: Die deutsche Wirtschafts- und Vernichtungspolitik in Weißrußland 1941 bis 1944 (Hamburg: Hamburger Edition, 1999); Wendy Lower, Nazi Empire-building and the Holocaust 
micro-, macro-, and meta-levels, only that it provides unfamiliar and perhaps useful perspectives, as I will hope to illustrate in this response. I am not alone in writing at the meso-level, of course; but I am seeking to show that the meso-level of region and policy might be more productive than (or at the very least complementary to) the more common meso-level of nation and experience. National history, however, has a powerful hold on the imagination and powerful defences, some of which are present in these reviews. Few historians will say outright that the national history in which they specialise is special because the nation in question is special. But many historians, when confronted by the obvious limitations of national history as framework, defend the nation by a leap to the meta-level of moralisation or theory. While they will not usually (in the West) claim that the nation itself is unique, they will claim that the national experience uniquely gives access to crucial moral or theoretical questions. I think of this tempting and frequent conflation of the national and the principled as Deutschnationaluniversalismus, although any large and important historiography, such as the American, seems to evince this tendency.

The indirect defence of the national framework usually works by way of 'theoretical' arguments that change the subject from history to comparison: whether the position taken is for or against comparison is irrelevant; the important thing is to recast the argument in a way that allows national history to continue untroubled. The 'theoretical' argument against comparison of nations or states or regimes serves to defend the purity of national history as an approach, though it is generally made by people who would never dream of explicitly defending national purity in another sense. But the consequence of taboos on comparison is precisely the survival of dominant national frameworks. The 'theoretical' argument in favour of comparison also, despite appearances, defends the purity of the nation and its history. In order to arrange a comparison, two nations or states (say Nazi Germany and the Soviet Union) must be first presented as analytically distinct. This methodological move shrouds what two regimes (in this example) have in common: territory and populations. The paradigmatic example of how both the taboo upon and the insistence upon comparison insulate preeminently national perspectives is the Historikerstreit, a debate about the Holocaust in which its victims and their homelands hardly figured. In the Nolte view, German history is so special that, despite every indication to the contrary, it is one of victimhood. In the Habermas view, German history is so special that normal historical discussion is unacceptable, because it might lead to conclusions like Nolte's. Thus from Left and Right is joined the march along the Sonderweg; as Thomas Kühne's essay demonstrates, there are still shields for this phalanx.

The transnational requires a certain penetration of national forms, which can generate anxiety. Another way to protect conventional national history from the transnational is to reduce transnational arguments to a neighbour's national history. Dan Diner, for example, begins his elegant essay with an imaginative etymology of the title of my book: 'evidently' I was thinking in Polish of kresy, which I translated into

in Ukraine (Chapel Hill: University of North Carolina Press, 2005); Christoph Dieckmann, Deutsche Besatzungspolitik in Litauen (Göttingen: Wallstein Verlag, 20II). 
English as 'borderlands', which then by assonance and consonance brought me to the neologism 'bloodlands'. Then Diner, to his credit, demonstrates that the book by no means keeps to the Polish framework that this suggests, often in (to him) surprising ways that seem to minimise the significance of Polish history. He could have taken this argument about the undermining of traditional Polish narratives much further: after all, I work to show that the number of direct mortal non-Jewish Polish victims of the German occupation was something like a million rather than something like three million, which until my book's publication was the standard account. I revise downward standard estimate of non-Jewish Polish losses from Soviet policy as well, for example those resulting from Soviet deportations from Soviet-occupied eastern Poland, which is the dominant contemporary meaning of kresy. ${ }^{3}$ I was not issuing these corrections of quantity and quality either to affirm or to deny a dominant account; I was doing it because this is what the present state of the evidence supports. But none of this is surprising, since the idea of the kresy had nothing to do with the origins of the book or with its title. Indeed, I have written an entire book explaining why the kresy framework, that is seeing Poland's eastern frontiers in an essentially colonial light, is inadequate as a framework for history. ${ }^{4}$

I certainly would not wish to understate the importance of the Polish language and Polish sources of all kinds in my work, however. After Jews and Ukrainians, at more than five and more than three million, Poles along with Russians and Belarusians died in the greatest absolute numbers in the bloodlands. Most of the Holocaust took place in occupied Poland, and most of its victims were Polish citizens. The most important collection of primary sources on the Jewish experience of the Holocaust are the archives of the Jewish Historical Institute in Warsaw. Many of the Jews (and for that matter Ukrainians and Belarusians) who died knew Polish and for that or other reasons their experiences were recorded and have been analysed in Polish. Many of the other crimes of the German and Soviet regimes were recorded by victims who wrote in Polish. A great deal of the important secondary literature on the Holocaust of the last five years has been published in Polish. ${ }^{5}$ The Polish state was the political entity of the greatest significance between Moscow and Berlin in the I930s, and its destruction coincided with the crucial escalation of Nazi mass violence. It is difficult for me to imagine how we could undertake a serious study of Nazi imperialism without incorporating sources from the major language of the country where most of its victims lived and perished. The problem, I think, is the assumption that if I use the Polish language (as I did, along with about ten others) I must be adopting

${ }^{3}$ Even my major account of a Soviet killing policy targeting Poles is one that was all but ignored by Polish historiography: the ethnic killings of the Polish national operation in the USSR in I937-8. It is worth mentioning that the pioneering work here was done by Russians: A. Ie. Gurianov, ed., Repressii protiv poliakov i pol'skikh grazhdan (Moscow: Zven'ia, I997).

4 The Reconstruction of Nations: Poland, Ukraine, Lithuania, Belarus, 1569-1999 (New Haven: Yale University Press, 2003).

5 Of particular note since the publication of Bloodlands are Barbara Engelking, Jest taki piękny słoneczny dzień: Losy Żyów szukajacych ratunku na wsi polskiej 1942-1945 (Warsaw: Stowarzyszenie Centrum nad Zagładą Żydów, 20II) and Jan Grabowski, Judenjagd: Polowanie na Żydów 1942-1945 (Warsaw: Stowarzyszenie Centrum nad Zagładą Żydów, 20II) 
a Polish national perspective - an assumption that contains within it the further assumption that within Polish culture there is only one perspective. Transnational history means using multiple national histories, but it also means disrespecting their forms. It requires familiarity with, and learning from, the multiple challenges to national history that lie within any given national culture.

One half of title of my book does indeed have a Polish source, although one that is as far from the idea of kresy as can be imagined. The greatest Polish novelist of the twentieth century was Witold Gombrowicz, also the most effective critic of the standard Polish historical discourse. He is one part of a duo that still defines Polish intellectual life. The great writer of the kresy, the historical novelist Henryk Sienkiewicz, is the other. To this day you can ask any Polish intellectual: 'Gombrowicz or Sienkiewicz?' and he or she will have a ready answer. The Second World War found Gombrowicz in Buenos Aires. Rather than return to the homeland, or write supportively patriotic fiction, he penned Trans-Atlantyk, a hilarious and traumatised parody of Polish self-understanding written entirely in a baroque Polish. In one passage the narrator opposes the idea of the 'fatherland' calling instead for a 'sonland' (not 'ojczyzna' but 'synczyzna'). ${ }^{6}$ Since I997, when I read Trans-Atlantyk, this idea of a 'sonland' has been important to me, since I have been seeking to write a history of nationality that emphasises that nationalism, although it presents itself within and is usually discussed within myths about the past, is in fact a politics of the future. I had completed then my first book, which was about a Marxist revolutionary, and wished to write my second book about families in which different siblings chose different nationalities and became important in different national movements and states. The title of this (still unwritten) book is Brotherlands, which is meant to convey the relationships between the Jewish, Polish, Ukrainian, German, Russian and French nations that are its subjects, as well as the reality that siblings might make different choices about identity as they anticipate different futures. This title I owe to Gombrowicz.

One of the reasons that I have not yet written Brotherlands is that I have written Bloodlands. Over the course of writing four other books that were about nationalism (among other things, as Mark Mazower recalls, ethnic cleansing and collaboration in the Holocaust), I came to the conclusion that national history, however pluralistic or critical or reflective, was inadequate to the history of eastern Europe in the twentieth century. ${ }^{7}$ Although the substance of national thought, politics, and actions was much influenced by Nazi and Soviet power, it was not in itself adequate to explain the origins, workings, and consequences of Nazi and Soviet power. Nationalism has much to do with the Ukrainian-Polish ethnic cleansing to which I devoted a good deal of attention, but the events could not possibly have taken place without both German and Soviet occupation. As east European historians had not quite acknowledged, the vast majority of German and Soviet killing, including the Holocaust, took place on

\footnotetext{
6 Witold Gombrowicz, Trans-Atlantyk (Cracow: Wydawnictwo Literackie, I996), II4 and passim.

7 In another discussion of this book I devote an entire article to the question of collaboration: see 'Collaboration in the Bloodlands', Journal of Genocide Research, I3, 3 (20II), 3I3-52.
} 
a territory that was smaller than the two empires but larger than any one national unit (whether understood territorially or demographically). With the opening of east European archives, we had the opportunity to unite the history of a region (understood non-nationally) with the history of the calamities such as the Holocaust and Soviet terror that most historians regarded as major events of the century. As I put aside critical national history and took up the European history of mass killing, I took the logical next step of presuming that national history would à plus forte raison be inadequate to explain the consequences of National Socialism and Stalinism. National history helps us to raise questions (why were we victims? why were we perpetrators? why did we stand by?) that it is incapable of fully answering.

Thus in my own personal intellectual history, Bloodlands, both as a project and as a word, arose as a pendant to Brotherlands, the book that I had meant to be writing. The origins of the term 'bloodlands' begin with Gombrowicz's transgressive liberation of '-lands' from traditional prefixes. The new prefix that I affixed to '-lands' was prompted by a Russian source. In the early chapters of the book I cite the Russian poet Anna Akhmatova several times, especially her 'Requiem'; as a native Russian-speaking commentator has already noticed, I do not cite what is perhaps her most famous line about her homeland in the text ('Любит, любит кровушку, русская земля'; 'it loves, it loves droplets of blood, the Russian earth') because I refer to it in the title. ${ }^{8}$ Insofar as I expand an idea from east European history, it is from Petersburg west and south rather than from Warsaw east and north, it is кровушка rather than kresy. The title seemed right to me because of a number of scenes in the book that I will not recite here, because so many people died in these places, each of them a particular concrete and very often literally a bloody death; and because of the plurality: not a single bloodland, but bloodlands, different homelands, big and small, but adjacent and interacting. It also seemed to fit because the argument has much to do with the interests of the two regimes in the land as they imagined it, and because I stress that people tended to die very close to home, in real places that we can name, rather than in realms of anonymity.

The metonym of anonymity is of course Auschwitz, which Adorno once thought should prevent us from writing and presumably from citing poetry, and Diner faults me for underestimating. The gas chambers of Auschwitz-Birkenau become widely known precisely because, unlike most important German killing sites, they were associated with a labour camp which Jews and others survived. Auschwitz is where Jews from (in Cold War terms) Western countries were killed, and thus Auschwitz was preserved as a memory during the Cold War. It helped that victims of Auschwitz were more likely to be bourgeois and thus suitable targets of comfortable identification, much more so, say, that Yiddish-speaking Jewish workers from Poland or Russianspeaking Soviet Jews. But Auschwitz is in numerical terms only a fraction of the

8 The commentator was Andrei Palchevskii, on the television programme Глибинне Буріння, taped 22 October 2oII. The entire poem is: 'Не бывать тебе в живых, Со снегу не встать. Двадцать восемь штыковых, Огнестрельных пять. Горькую обновушку Другу шила я. Любит, любит кровушку Русская земля.' 
horror: five sixths of the Holocaust happened elsewhere, and, crucially, earlier. Diner proposes that Auschwitz is symbolically important because it seems to prove that German policy was from the beginning to kill all Jews. But we know that until I94I German policy was to deport Jews, and that until I939 this policy was implemented with some measure of success. German policy from beginning to end was to eliminate all Jews under German control; the crucial question, it seems to me, is when and how this became a policy to kill them. This is a question that Auschwitz cannot answer.

Physical extermination was already German policy well before Auschwitz became the extermination facility with which we are familiar. Whether or not there was a camp at Auschwitz the Holocaust would have happened; indeed most of it happened before the major gas chambers at Birkenau were even on line; the same cannot be said about the German invasions of Poland and the Soviet Union - without these, the Holocaust is inconceivable. Diner might be right that the emphasis on Auschwitz permits us to preserve a certain centrality of the Holocaust to European history; but in current commemorative discussions this is a centrality that recalls a geosynchronous satellite poised above the earth's equator. There is gravity, there is darkness, there is repetition, but there is too little contact. (Consider, just as an example, two profound and wonderful books of the first decade of the twenty-first century: Saul Friedländer's Years of Extermination (2007) and Tony Judt's Post-war (2005). Each of them seems to contain a portrait of Europe, and yet there is almost no way to make the two of them communicate with each other.) In my view, the significance of the Holocaust can only be firmly established when its events are anchored in European history, which means that we must add to Auschwitz in such a way that the symbol can be defended as part of a history that is still larger, more horrible, and more personal than the symbol conveys.

Bloodlands is meant to describe and explain each Soviet and German killing policy as a subject of interest in its own right, but in its geographical and temporal conservatism it is also meant to put in place some of the factors that we need to understand the origins of the Holocaust. We cannot understand the Holocaust without understanding that its victims inhabited lands touched by both German and Soviet power. But we must be as specific about what this means. German-Soviet interaction transcends 'learning', which Jörg Baberowski emphasises in his essay.' The two leaderships did not, in my view, learn very much from each other; and the category tends to make the interaction seem more intellectual and abstract than it was. They knew far less about each other than we do know about either of them, and this is true of some of the crucial examples. The Soviets rather than the Germans, for example, first undertook mass ethnic shootings, but there is no evidence that this was a lesson for the Germans, and much suggestive evidence that it was not. Territory allows us to remember that there were peoples and polities between Moscow and Berlin, which might be overlooked, disregarded or targeted for violent transformation or destruction. But they were simply there, with their own projects and purposes, in

\footnotetext{
9 Baberowski presses the dialectical point harder in his German-language review in Die Zeit, 26 July 2OII, where he refers to German policy as, in some measure, an answer (Antwort) to Soviet policy.
} 
a sense that is not reducible to German or Soviet ideas about them. Territory allows us to see interaction in all of its complexity, including the moments, very frequent, when ignorance or miscalculation means that the Germans or the Soviets encounter something that they do not expect.

Kühne takes a position exactly opposing Baberowski, namely that I overstress mutual interaction, and thus tend to collapse the two regimes into one another. The whole premise of Bloodlands is that two different regimes had in common a certain special territory, which because they committed most of their crimes there warrants study. This does permit certain new comparative insights, I think, but it does not make of the book a comparison. In their common stress on learning and comparison Baberowski and Kühne are in dialogue with each other rather than with my book. Kühne organises his text around his personal opinions about my putative motives for writing the book as well as his gestures towards what he takes to be others' (uncited because non-existent) 'readings' of it. His remarks about both motives and reactions can be easily countered by what I would unhesitatingly call the available evidence; my public affiliations with institutions associated with the memory of the Holocaust and my public record on the political issues he raises is quite unambiguously the opposite of what he implies. ${ }^{10}$ At the book launch in Kiev I was attacked by a neo-Nazi for purveying the 'myth' of the Holocaust. Anyone who knows anything about the east European far Right knows that I am a target rather than a darling, and that for some years now. ${ }^{11}$ The two best (most laudatory and most

10 For my views about the contemporary far Right and Holocaust memory consult articles on Ukraine, Austria, Norway and Lithuania in the New York Review of Books blog and the editorial about the United States in the New York Times (I7 Oct. 20IO).

11 Readers who do not know east European languages can verify this simply by watching the videos of book talks about Bloodlands in the US and Canada. Predictably I take a beating for putatively overemphasising, for example, the role of Lithuanians in the Holocaust, or for putatively understating the number of Ukrainians killed in the famine of 1932-3. The opposition to the book has, in general, come from ethnic nationalists of all varieties, a kind of nationalist international. Kühne cites Efraim Zuroff, which is a curious choice, since the two things that Zuroff is admirably forthright about in his review are (I) that he is defending the metahistorical nationalist position that there are nations of perpetrators and nations of victims and (2) that he does not like my book. That a reviewer who is forthright about his nationalist premises should conclude negatively is no surprise. Zuroff does claim, counterintuitively, that nationalists of other national orientations like my book, but gives no evidence or cases. This move, which Helvétius would have called 'interested error', is routine. Zuroff's text typifies the reflexive nationalist response, regardless of national orientation: no fault is found with the historical scholarship of the book, but the claim is made - always without examples - that history thus presented must somehow be helping the politics of someone else's national narrative. Of course, the putative beneficiaries then take exactly the same position! They too cannot pinpoint what is wrong with the book, but feel sure that it must be helping someone else. And so on. The structure of this nationalist response is absolutely identical, regardless of the nationality in question.

Unlike Kühne, I'd propose to read such texts critically, and to make sure that generic nationalist terms of engagement are not confused with scholarly critique or, least of all, political events in the real world. Insofar as this suggests an issue of theoretical interest, it is this: transnational scholarship constitutes a general problem for the nationalist position that history is the zero-sum politics of competitive ethnic victimhood. But it is a shame, even in a footnote, to expend so many words on this matter, since that risks overshadowing what is truly interesting in the reception of the book: the remarkable toleration of and generosity towards new interpretations in Europe, North America, and Israel alike. The nationalist reaction has been the same everywhere, but it has also been marginal everywhere. 
interesting) reviews of Bloodlands were indeed written by east Europeans - both of the gentlemen in question are child survivors of the Holocaust, and one is a leader of his country's leading anti-fascist organisation. I am of some interest to certain political milieux in eastern Europe - these are groups such as the idiosyncratic neoMarxists at Political Critique in Warsaw and Visual Culture Research Centre at the Kiev-Mohyla Academy, who tend to understand the book's transnational approach as international or anti-national. It apparently, though regrettably, has to be stressed that eastern Europe is not a zone of imagination and projection but a real place inhabited by actual people, with published and broadcast discussions of my book that can be read and considered; it is distressingly postcolonial, in the worst sense, for a scholar of Germany to conjure up imaginary actions by imaginary east Europeans in order to bolster his own provincial perspective.

Kühne's swipes at what he imagines to be my person and politics suggest important differences about the fundamental issue of the methods and meaning of Holocaust scholarship. I am unembarrassed to say that the Holocaust took place in what I am unashamed to call reality, and thus that our discussions of it must resist the temptations of representation, which, as in Kühne's essay, often means the liberty to metastasise the personal preoccupations of a given scholar at a given moment as 'theory'. The emphasis on representation is usually, as it is in Kühne's text, strikingly conservative, since it defends unreflective and historically contingent categories of everyday cognition that we find comfortable against findings and arguments that we do not. But history is not about comfort. Kühne's essay is an unmistakable example of elevating the habitual categories of national discourse to metaphysical status in order to preserve them. We can do better than this. Since the Historikerstreit, the history of the Holocaust has improved to an almost unbelievable degree, and the leading historians have been Germans; since the Historikerstreit, we have gained, astonishingly, access to records and experiences in eastern Europe, where the Holocaust took place. This allows us to write new and better history, and we must do so unhindered by the politics of the Federal Republic of Germany in the second half of the I980s. In fairness, almost every reader and reviewer aside from Kühne has understood this point.

The etymology of the Polish word kresy is probably German, from Kreise, or circles. The image is one of a central power that ripples outward, eventually becoming indistinct and then disappearing. As German historians increasingly understand, a history of the Holocaust written only from Berlin cannot fully accommodate the experiences of those who were drowned under these waves, since $98 \%$ of the mortal victims of German killing policies did not know the German language. It also cannot fully accommodate the non-German forces in the world, which Germans confronted and to which they had to react, but which they did not necessarily understand. History, as Marc Bloch reminds us, is about understanding; and if we can have an image of Jews, or Poles, or the Red Army, or the Communist party, that is independent of the Germans' own, we will have taken one step towards understanding the world affected by German policy that the Germans themselves could not have taken. Baberowski's point about learning is an invitation to the actual 
issue of interaction rather then the issue itself; Mazower goes further and, quite correctly, argues that the policies of mass murder in the bloodlands could be better understood against a broader European backdrop of mass killing. Although I could not, without writing a quite different book, account for all of the imperial histories Mazower mentions, I would agree that we need multiple accounts of violence to make sense of individual cases. Nothing in previous Jewish history, for example, was much like the Holocaust; the experience of Armenians under Turkish rule is far more similar to the Holocaust than were the pogroms of Jews of the I880s or I920s. This is one reason why we must understand the Soviet Union: the highly organised mass shooting of members of Soviet ethnicities in the I93os was also more like the Holocaust than was any prior event in Jewish history.

Recent antecedents in the history of European oppression are a subject of the book's first chapter, but in the quantitative terms in which I defined my subject, what happened in the bloodlands between I933 and I945 was exceptional by any measure, even that of the twentieth century in Europe; in addition to the broader explanations which Mazower has so advanced and refereed, we need an appeal to overlapped ideas and practices of neocolonialism applied to the same place. ${ }^{12}$ I began not from the assumption that the two regimes were qualitatively different from all others, as Mazower suggests, but rather from the simple observation that the scale of deliberate killing of non-combatants was far greater in the time and place of their overlap than in any other event in modern European history. The argument is about the world in which these two regimes functioned: that each undertook a differently ambitious project of neocolonialism conditioned by the reality and perception of British world power, each thus tilting towards the Eurasian heartland and into contact with the other. Other regimes do in fact figure in the account, if not as analytic 'comparands'. The unappealing but not especially violent Lithuanian Smetona, the Polish sanacja, and the Hungarian Horthy regimes of the late I930s figure as instances of what happens when governments are removed by force; the Romanian Antonescu regime figures, right in the middle of the book, as a contrast to the Nazi regime, one which helps to explain what was indeed different about Nazi Jewish policy. But Mazower is right: I do conclude that the Soviet and the Nazi ideas were ambitious as other ideas of transformation were not; that they overlap in both territorial design and territorial implementation means that we should expect an overall outcome like the one which, so tragically, obtained. The particular explanation of particular policies required me to make specific arguments that, I can only hope, will contribute to the larger discussion of state violence, to which of course I owe considerable debts. ${ }^{13}$

In contrast to Mazower, Diner worries that broader arguments about violence are like a 'severability clause', since the special character of the Holocaust will be somehow elided. These are apparently contradictory positions but, like the apparently

12 See for example Mark Mazower, 'Violence and the State in the Twentieth Century', American Historical Review, I07, 4 (2002), II47-67.

13 I take Mazower's point about references. In the bibliography, which is quite long as it is, I mentioned chiefly recent works that bear directly on the particular German and Soviet policies of mass killing. Naturally, this does not exhaust the historical literature from which I have learned. 
contradictory positions of Kühne and Baberowski, I believe that they can be answered together. The framework used in Bloodlands permits us to apply general arguments to the most important case of state violence, and to explain the Holocaust in a way that preserves the distinctiveness of the event while securing it within European history. So by way of answer to all four reviews, let me now crystallise its causal explanation of the Holocaust. ${ }^{14}$

\section{The test: Bloodlands as Jewish history}

The First World War is the foundational calamity. It killed millions while furnishing millions more with youthful experience to be endowed with meaning, destroyed an old order while giving rise to new ideas of empire, and ended a globalisation while bringing new dreams of autarky. It brought an east European colony, including the world's major Jewish population, briefly but fatefully under German rule. Having sent Vladimir Lenin in a sealed train to Petersburg, Imperial Germany exploited the Bolshevik Revolution to win the war on the eastern front and establish east European client states in I9I8. The most important of these, Ukraine, was to supply the grain to feed German troops fighting on the western front, who were defeated before the impracticality of this scheme became entirely apparent. After the German defeat on the western front and the peace at Versailles, many Germans were tempted by the idea of a 'stab in the back' by German Jews and socialists. German troops returning undefeated from the east were prone to blame the Bolsheviks, who filled the power vacuum that they left behind, and whom they associated with eastern Jews.

In the German republic of the I920s, Adolf Hitler and his National Socialist party articulated these anti-Semitic explanations for Germany's woes: Jews were responsible for all that ailed German civilisation; Jews created the communism that blocked Germany from needed living space in the east; and Jews were responsible whenever Germany's aspirations were resisted by outside powers. Ideology reduced Jews to objects, causal forces that could be flexibly invoked to explain Germany's fate, without subjectivity and worth as individual human beings. But ideology is nothing without economics, which in the time and place was territorial and agrarian. Hitler believed that the reconquest of Ukraine from the Bolsheviks would make Germany self-sufficient in food, even as it allowed the German race to propagate and purify itself through pastoral colonialism. Germany's own Jewish population was quite small, but any such plan for eastward expansion would require the renewed control over the east European lands where most Jews lived: the western Soviet Union, and Poland which stood between.

In the I920s, when Hitler was writing his books and the Nazis were losing elections, this could all appear a distant dream. By the terms of Versailles, Germany not only lost any claim to Ukraine, Belarus and the Baltic region, which it controlled in I9I8, but some of its own pre-war territory to a newly independent Poland.

14 The arguments to come are extensively footnoted in Bloodlands. 
Immediately after the war, in I9I9, it was Poland rather than Germany that fought and won a war of destiny with Bolshevik Russia. The Treaty of Riga of I92 I confirmed the existence of Poland as an independent republic, and established that Bolshevik power would take the form of a state with external borders and internal national frontiers: the Union of Soviet Socialist Republics established in I922. The bulk of Europe's Jews were divided between Poland (about three million) and the Soviet Union (also about three million, most in the western Soviet republics of Ukraine and Belarus, which bordered Poland.) Significant numbers of Jews also found themselves in post-war Hungary, Romania, Czechoslovakia, Lithuania and Latvia.

In the decade after Lenin's death in I924, Josif Stalin rose to power with a resolution of the great ideological enigma of young Soviet power. According to Marxism, revolutions were to take place in modern industrial societies such as Germany, not in backward agrarian empires such as Russia. Lenin and his allies had made a revolution in the Russian Empire, believing that German comrades and workers would quickly come to the rescue. When German revolutionaries did not triumph in the post-war chaos of I9I9, and when Poland blocked the way to Germany in I920, Soviet leaders adapted their revolutionary institutions to the needs of a new state. The disciplined Communist party and the extraordinary state police became the tools of a revolution from within, since no revolution was coming from without. Stalin and other leading Bolsheviks proposed a vast modernisation project that would exploit the agricultural resources of the Soviet Union to promote its industrialisation. In I924, as Hitler was writing about National Socialism for the German race, Stalin proposed 'socialism in one country'. Both of these visions concerned the entire Soviet Union, which included much of the world homeland of Jews.

In Germany Hitler owed the sudden growth in the popularity of his party in the early I930s to the Great Depression rather than to his anti-Semitic platform; but once he became chancellor in 1933 he used the politics of anti-Semitism to change the state and the society. The progressive exclusion of German Jews from political, economic and civic life permitted the Nazi regime to penetrate private life and establish the loyalty, or at least the passivity, of the non-Jewish majority. The emigration of German Jews corrupted Germans with what had been Jewish property and businesses. Meanwhile, Hitler freed the army from restraints imposed by the Versailles peace and promised his generals a redeeming campaign in the east. Although the final goals were imprecisely defined, the basic idea was to control the western Soviet Union, which meant controlling Poland, which meant controlling most of Europe's Jews. Hermann Göring and then Heinrich Himmler centralised the various police forces and prepared for a coming racial war, which was to be led by Himmler's SS.

The Jewish view from Poland and the Soviet Union, where most European Jews lived, was different. In Poland, where the share of Jews in the population was about twenty times greater than in Germany, Jews were a significant electorate, and antiSemitism was an integral part of democratic politics from the beginning. The very first Polish president was assassinated by a right-wing fanatic in 1922, outraged that his victim was the candidate of the Left and the national minorities. When Józef Piłsudski 
established a dictatorship in 1926, his regime established equal civil rights for its Jewish citizens. Although Jewish political life in inter-war Poland evinces an imposing complexity, the most popular option was loyalty to his regime. After Piłsudski's death in I935, his successors appealed to the anti-Semitism of Piłsudski's nationalist enemies. Yet Jewish life in Poland was not simply a story of woe. Social advancement was very possible, as demonstrated by the linguistic assimilation of young urban Jews and the success of Jews generally in the professions and the arts. Nor did very many Jews wish to leave the country. Poland's leaders believed that there was a 'Jewish problem', in that Jews were too numerous to be assimilable and blocked the entry of Polish peasants into the middle classes. In the late I930s, the regime encouraged the Revisionist Zionists, who wished to move Polish Jews to Palestine as quickly as possible. The obvious problem was that the British, who controlled Palestine, opposed the scheme. The fundamental problem was that few Polish Jews were interested.

The Soviet Union, meanwhile, was the only anti-anti-Semitic country in the world. The Soviet state had of course expropriated Jewish businesses, liquidated Jewish political parties, and suppressed the practice of Jewish religion. Yet young Jews took advantage of the educational and employment opportunities offered by the new system, largely unavailable to them in the Russian Empire. Jews became so prominent in Soviet party and state functions that Soviet affirmative action was designed, in places such as Soviet Ukraine, to recruit the local non-Jewish majorities to universities and administration. Affirmative action was quite successful by the early I930s, although the number of Jewish commanders in the Soviet state police would remain very high until the Great Terror of I937-8. In those years the Soviet leadership used the NKVD to kill about 700,000 people belonging to categories deemed dangerous to the regime, among them a quarter of a million people shot in ethnic actions. During the Terror, Stalin purged NKVD officers for supposedly insufficient vigilance; after the Terror was he purged them for supposed excesses. The result was that Jews lost their prominent place in the NKVD, and were replaced by the Russians and Ukrainians who dominated the state police thereafter.

In the I930s, Hitler was dreaming of a great repressive empire, but Stalin actually controlled one. The Soviet state police, unlike any German institution at the time, was capable of massive and precise killing and deportation. In the Nazi mind, the obvious evidence of Soviet institutional capacity was explained away as a racial anomaly. Hitler and others imagined, anti-semitically, that the elimination of the Jews who, they believed, ran the regime would lead to the collapse of the Soviet state, since the Slavs and Asians who constituted the bulk of the Soviet population would be helpless animals without their clever Jewish leadership. Thus the dream of seizing the fertile soil of Soviet Ukraine (and oil from the Soviet Caucasus) seemed realistic when combined with the fantasy that the Soviet Union was a fragile Jewish state. No matter what actually happened in the Soviet Union, Nazi ideology could adapt it to this paradoxical view: the Soviet state was strong in its vast resources, but weak in its racially untenable regime.

The most robust challenge to the Nazi notion of Soviet fragility was Stalinist modernisation, well under way when Hitler came to power in I933. That year 
Stalin declared the completion of his first Five-Year Plan. Collective farming was introduced, millions of peasants had become workers, thousands of factories had been constructed, cities had become metropolises. Literacy rates were quickly increased, of key importance to a propaganda state. People in European countries bordering the Soviet Union, such as Poland, learned of the costs from the refugees: the starvation of at least six million Soviet peasants, most of them in Soviet Ukraine, and the creation of a vast system of concentration camps. In France and Spain, the Five-Year Plan could seem like a plausible alternative to capitalism. Germany was in the middle: here the Five-Year Plan was a subject of intense dispute. Germany's large Communist party was instructed by Moscow to follow a line of 'class against class', in part because a fierce but fruitful class struggle was the Soviet explanation of how the deaths of millions of Soviet citizens was a step towards utopia. According to this line, German Communists were to treat German socialists as class enemies, as 'social fascists', rather than as allies against Hitler. Without the ideological obstinacy of the Communists, which frightened German voters, and without the fragmentation on the German Left, Hitler would have had greater difficulties in winning elections.

Hitler's response to Stalinist modernisation in his electoral campaign of early I933 polarised the discussion to such an extent that historical discourse has never recovered. Even as German Communists and socialists failed to co-operate against him, Hitler presented both of his opponents on the Left as 'Marxists' in thrall to Moscow, and starvation in Soviet Ukraine as the consequence of 'Marxism'. Even as people in Soviet Ukraine were still dying slow and awful deaths from starvation and disease, their agony and death became an instrument within a polarised political discourse that dominated the I930s, powerfully restoring the Left-Right opposition born of the French Revolution, and leaving a ringing echo that we still hear. When, the following year, Stalin began to organise European political opposition to Nazi Germany under the heading 'anti-fascism', the full logic of polarisation was established. One was either for fascism or against it. The Five-Year Plan was a great success or a great failure, and one had to choose sides.

In the history of Holocaust, the Soviet Five-Year Plan barely figures. If it is mentioned, it is only as a minor element of the story of Hitler's political rhetoric on I933. To my knowledge, no historian of the Holocaust has noted that Soviet starvation policies killed far more Jews in the I930s than did any action of Hitler's that decade. For that matter, the Soviet Great Terror of 1937-8 also killed far more Jews than any action of Hitler's that decade. Indeed, there were more Jews in the Soviet concentration camps in the I930s than in German concentration camps. Of course, the killing of roughly a hundred thousand Jews in the Soviet Union in the I930s is not part of the Holocaust; but it does remind us that there were about three million Jews in the Soviet Union, that Soviet organs of oppression were vastly more developed than their German counterparts, and that state power and hunger are indispensable parts of any description of the lands where Jews lived.

The significance of the famine in Soviet Ukraine for the Holocaust is more profound still, since it provides an early and powerful indication of the social costs and political consequences of a ferocious political contest for the control of territory 
and fertile soil. We now know that Stalin in 1932 and I933 blamed Ukrainians for the famine that arose from his policy of collectivisation, and deliberately chose a series of policies designed to starve the inhabitants Soviet Ukraine. Thereafter Hitler's vague notions of living space become, in plans developed by Hermann Göring's Four-Year Plan Authority between I936 and I94I, ever more precise blueprints for Ukraine and other lands to be conquered from the USSR. The Soviet collective farm, the instrument proven capable of starving people by the million in I933, was to be preserved so that tens of millions of people - including the majority of Soviet Jews could be starved under German rule. Like Hitler's vague notion of Lebensraum, these more precise plans concerned the homeland of millions of Jews.

When Stalin showed that he could starve populations, he also showed that he could control them. But of course it was not Stalin personally who starved millions of people in Soviet Ukraine in I933: it was local party activists and state functionaries who fulfilled the requisitions and watched others starve. In Soviet Ukraine, where the famine was concentrated, most of these people were themselves Ukrainians. In other words, Ukrainians killed other Ukrainians, their neighbours, by starvation. Both Hannah Arendt and Leszek Kołakowski regarded this as a crucial turning point in the emergence of Stalinism. It reminds us that participation in policies of mass killing can hardly be exhaustively explained by references to ethnicity. All in all, more Ukrainians took part in Soviet killing policies in the I930s than in German killing policies I94Os, and some took part in both. One might propose that Ukrainians were somehow prone as a nation to collaborate with whichever form of ideological power presented itself; surely it is wiser to record that Ukrainians found themselves between the two most violent projects of transformation in the history of Europe.

Ukrainians were the most numerous population in the lands where the Holocaust took place, but all too often they only appear in histories of the Holocaust in 1942, where guards in the death facilities where Jews were gassed are identified as Ukrainian. By that time, between three and four million Ukrainians had been deliberately killed by hunger since Hitler came to power on the lands where the Holocaust took place, first by the Soviets in I933, then by the Germans in I94I. Soviet starvation was an unintended consequence of collectivisation that Stalin directed against putative enemies; German starvation was actually meant to kill thirty million Soviet citizens, but had to be scaled back. What the Germans learned when they invaded the Soviet Union in I94I is that it is much easier to get one relatively small group to help in the shooting of another relatively small group than it is to induce an entire society to starve itself. In some measure, the German starvation policy contributed the personnel used for a policy to which there was no Soviet counterpart, the mass murder of Jews. The first guards at the death facilities, some of whom who were Ukrainian and some of whom were not, were recruited from the German starvation facilities. They were all Soviet citizens, as indeed were most collaborators in the Holocaust.

The foundation of social power is food; the foundation of international relations is statehood. In order to eliminate the Jews, Hitler had to alter the Europe state system in such a way that German power was present where Jews lived. Hitler always knew that he would have to destroy Soviet power, but the fate of Poland was never 
precisely forecast in his writings, and was decided six years after he came to power. Between early I934 and early 1939, Berlin courted Warsaw with plans for a joint invasion of the Soviet Union, which as Polish leaders surmised would have to end with Poland as a German satellite. Warsaw however maintained an equal distance between Berlin and Moscow, signing non-aggression agreements with both. Stalin ordered the 'Polish national operation' that killed some IIo,ooo Soviet citizens in part because he was convinced that Poland would never be an ally of the Soviet Union. By summer I939, Hitler also understood that no alliance with Poland was forthcoming, and planned for a war against Poland. Germany had absorbed Austria and the north-western rim of Czechoslovakia in I938. After Germany had dismantled what remained of the Czechoslovak state in spring 1939, Britain and France offered Poland territorial guarantees. Because Poland, Britain and France offered resistance, their defeat would have to precede Hitler's war of preference against the Soviet Union.

In accordance with these tactical priorities, Hitler sealed a military alliance with the Soviet Union in August 1939. The German-Soviet invasion of Poland that quickly followed that September began a world war, destroyed the Polish state, and brought two million Jews under German power. For the first time, the special Einsatzgruppen were entrusted with mass murder: the destruction of the Polish political class. Eastern expansion, enabled by the Soviet alliance, meant that Nazi leaders were confronted with large populations of Jews, with only hazy and impractical ideas of how they might be removed by deportation. The German incorporation of western Poland and the creation of a colony known as the General Government did not offer Germany any clear avenue for the 'strengthening of Germandom', to cite Himmler's new mandate. Germans were brought to the incorporated territories from the Soviet Union, even though Hitler planned to colonise the Soviet Union for Germans. Poles and Jews were deported east from the incorporated territories to the General Government, which moved them only a few hundred kilometres. Jews from the small towns were deported to ghettos in the big cities, but their final destination was still unknown. The high level of confusion was evident when the Germans asked their Soviet allies in early I940 if they would take these two million Jews; the answer was of course in the negative. The chaotic ghettoisation of Jews meanwhile set in motion a social transformation in Poland. Poles, themselves disadvantaged by an exploitative German occupation, moved into Jewish property and took up traditional Jewish trades. This meant that many Poles had a powerful reason not to want them to return from the ghettos.

Though we cannot know what would have happened to the Jews of Poland had the Polish state continued to exist, we do know that the end of statehood was a fact of fundamental importance for the Jews of Europe. The German mass murder of Jews took place in zones where pre-war statehood had been destroyed (Poland and the Baltic states) or displaced (from the western Soviet Union). In German allies such as Hungary, Italy, Romania and Bulgaria, as indeed in Germany itself, Jews had about an even chance of surviving the period of Nazi power. Jews who lived where pre-war statehood was destroyed or displaced had about a one in twenty chance of 
survival. ${ }^{15}$ This is a fundamental difference. So long as a pre-war state existed, there was some possibility that German allies would present control over their Jews as a matter of sovereignty, that a foreign policy consideration would intervene, that some Jews would have some recourse to legal institutions, that there might be instances at work which were not bent on the Jews' complete destruction. Where the state was eliminated, the blood-dimmed tide was loosed. Jews were at the mercy of German power, and of local populations (sometimes anti-Semitic, sometimes not) freed of legal regimes, often suffering from hunger, and usually desirous of social advance during an exploitative colonial occupation. To be sure, individuals within these local populations were morally responsible for their behaviour, but the entirety of Western and indeed Jewish traditions of political thought demands that we first look for the state before we try to explain the behaviour of a society.

Before the Holocaust began in I94I, four east European states were destroyed: Poland by the joint efforts of Germany and the Soviet Union in I939, and the three Baltic states by the Soviet Union in I940. Both the Germans and the Soviets not only used force to destroy state institutions, they sought physically to eliminate the human beings who had constituted and might reconstitute the political class. Once Estonia, Latvia and Lithuania were incorporated as Soviet republics, the Soviet terror apparatus was installed. Under Soviet rule political elites and ostensible class enemies were deported to the Gulag in the tens of thousands, and shot in NKVD prisons in the thousands. The largest wave of deportations was under way when Germans arrived in the Baltics themselves in summer I94I, blaming the Soviet occupation on Jews. The combination of Soviet oppression and German propaganda is often adduced to explain the collaboration of Lithuanians and Latvians in the murder of Jews that quickly followed when their countries were occupied for a second time in two years. Some people, no doubt, endorsed the Germans' anti-Semitic explanation and wanted revenge. Others were trying to cleanse themselves of their own prior collaboration with Soviet power by endorsing the Nazi identification of Bolshevism and Jews. After all, most collaborators with the new Soviet regime of I940 had not been Jews. More generally, Balts felt humiliated that they had not resisted Soviet rule. However one assesses these motivations, the prior destruction of the state by the Soviet Union is indispensable to their existence and their political uses. Precisely because the Soviets had destroyed the Baltic states in summer I940, the Germans could pose as future liberators to Baltic nationalists for a full year. They could welcome right-wing politicians in Berlin, and use them to organise the killing. Ukrainian nationalists underwent a similar experience. A marginal underground force in interwar Poland, they gained authority in 1939 when the Polish state was destroyed and hope in I94I when they thought that Germany would destroy the Soviet Union. Like Baltic political collaborators, Ukrainian collaborators bear the responsibility for their own politics and their own actions; but in both cases the chain of events enabling their collaboration begins with the destruction of states.

15 Including western and southern European examples would require addition categories such as 'puppet state' and 'German direct rule', but the argument would be the same. 
The argument thus far has proceeded through the categories of ideology, agriculture and statehood. Though sovereignty was the fundament of the international order, and food the basis of economic order that both Nazi and Soviet ideology sought to transcend, there remained nevertheless one superpower that ordered the globe, transcending normal notions of statehood and controlling food supplies: Great Britain. Hitler always knew that the Royal Navy could prevent Germany from becoming a colonial power in the traditional, maritime sense. Stalin, for his part, saw Soviet self-colonisation as the alternative to British-style overseas empire. For both Hitler and Stalin, Ukraine was to be the source of self-sufficiency and thus self-defence against British power, understood either as the cat's paw of London Jewry or the handmaiden of international capitalism. After the German attack on Poland in 1939 brought London into the war, Hitler thought about how this undesirable and perhaps unwinnable conflict with Britain could be brought to an end. Surely the defeat of France in June I940 would cause the British to withdraw. If not that, then no doubt the bombing of British cities and the threat of invasion that summer would convince. When none of this worked, and the British remained in the war, Hitler's thoughts returned rather quickly to the Soviet Union.

As of spring I94I, Hitler had won himself into a standstill, without fundamentally altering the world order, and without realising his own vision. He had brought Great Britain into the war as an enemy, and could not slow its rapprochement with the United States. He was in an alliance with the Soviet Union, though the point of the war was to destroy it. Germany was dependent upon food (and energy) supplies from its Soviet ally, and could not expect reliable replacements from overseas with Britain in the war. Hitler had vowed to annihilate the Jews of Europe, but had brought two million Jews under German power for nearly two years without doing so. Any idea of removing Jews by sea was absurd so long as Britain controlled the seas. In Hitler's mind, the only apparent solution was to go ahead with attack on the Soviet Union, in the hope that this would discourage the British, provide a place to deport the Jews over land, assure supplies of food and oil, and create the paradise of Lebensraum. The invasion of the Soviet Union of June I94I thus rested on four plans, reflecting both the needs of the moment and years of racist imperial contemplation. First, the Soviet state was to be destroyed militarily in a matter of weeks in summer I94I. Second, tens of millions of Soviet citizens would be starved to death that winter as food supplies were diverted west to Germany. Third, the Jews would be driven eastward across the Urals into Asia in a final solution. Fourth, the western Soviet Union would be transformed into a German agrarian colony.

German (and allied) forces quickly conquered the western rim of the Soviet Union, and thus controlled most of the lands of traditional Jewish settlement - Soviet Ukraine and Soviet Belarus as well as pre-war Poland and the pre-war Baltic states. As in Poland, the Einsatzgruppen were to eliminate the political class, defined antiSemitically in the USSR to include Jewish men of military age. In Lithuania two Einsatzgruppen aided by numerous Lithuanians began to murder Jews. In the swamps of occupied Soviet Belarus, Himmler had his Waffen-SS kill thousands of Jews, including women and children. To the south, Hungary and Romania drove Jews 
to the east. In the Hungarian case, this meant forcing Jews into German-occupied Soviet Ukraine. This led to the first massive shooting action, at Kamianets Podilskyi in August I94I, where more than twenty thousand Jews were shot. As in all succeeding mass shooting operations, German Order Police took part. In September I94I, the Germans murdered more than thirty thousand of the Jews of Kiev, an operation coordinated by civilian, military and police authorities. Yet Soviet state power was still clearly in evidence behind the advancing front. Stalin deported hundreds of thousands of ethnic Germans from Volga River region, making a mockery of Hitler's claim that 'the Volga will be our Mississippi'. Hitler ordered the deportation of German Jews to eastern ghettos, where local Jews were killed to make room for them. This established a fateful connection between the prior idea of deportation and the new practice of mass shooting. Here was the outline of the final version of the final solution, physical extermination of the Jews.

Hitler organised both of his major political tasks, the mastery of German society and the destruction of the Soviet Union, around anti-Semitic notions of Jewish dominance. But scapegoating Jews worked far better in the myth-soaked world of German national politics than it did in the harder international realms of diplomacy and warfare. When the Soviet state did not collapse, improvisation began. After a few months, plans to starve tens of millions of Slavs were scaled back. The Germans indeed killed about three million Soviet prisoners of war in the horrible POW camps know as Stalags and Dulags, often nothing more than barbed wire around an open field. Beginning in October I94I, however, the Germans began to recruit collaborators from among the hungry Soviet prisoners, preferring where possible ethnic Germans (on racial grounds) and ethnic Ukrainians (on the logic that Ukrainians had suffered under Soviet rule). Once the recruitment of captured Soviet citizens began, an argument for preserving the lives of some Jews was removed. If Slavs could be used as labour, there was less need to feed Jews in ghettos. Soviet citizens released from the starvation camps were then used to assist in the ongoing killing of Jews, either in the continuing shooting operations, or in the new death factories that were under construction in occupied Poland.

After the Red Army drove back the Wehrmacht at Moscow and the United States entered the war in December I94I, the grand idea of German colonisation gave way to the reality of a long war. At some point or points between autumn I94I and spring I942, Hitler conveyed his wish for the total physical annihilation of Jews. Thus one element of his imperial vision, the elimination of the Jews, came to stand for the whole. To this end were mobilised German Einsatzgruppen, German policemen, German soldiers, and locally-recruited police, all of whom were supposed to be much further to the east than they actually were, administering and controlling a massive post-Soviet colony that never came to be. To this end as well were subordinated the institutions that were meant to direct colonial policies of destruction. The area around Lublin, initially a laboratory of German colonisation plans, became instead the testing ground of a new means of killing Jews. Soviet citizens, now working for the Germans, helped to construct and guard facilities at Bełżec and Sobibór, where Polish Jews, held in ghettos since I940, were gassed in I942. That spring and summer the policy 
of extermination became visibly more comprehensive. The Germans built a third major killing facility, at Treblinka, added gas chambers to the concentration camp at Auschwitz, and asked their allies to send their own Jews to occupied Poland to be murdered. The largest of these groups, by far, were the Hungarian Jews, dispatched after the Hungarian government tried to leave its alliance with Germany and was overturned by the Germans.

German policy towards Jews was in an important sense consistent: at first they were all to be deported, and then they were all to be killed. The crucial change in policy, from deportation to killing, took place in eastern Europe, where the German racial empire was to arise, where most Jews lived, and where the technologies of mass killing were institutionalised. German power in eastern Europe was sufficient to destroy states (although here Soviet power was just as important), and to establish a politics of want (familiar to the Soviet citizens who constituted the bulk of the collaborators), but insufficient to replace class with racial empire. The shift from the deportation to the extermination of Jews was in part the consequence of the failure, or indeed the internal contradictions, of Nazi colonial plans. The deprioritisation of the murder of Slavs and the prioritisation of the murder of Jews in the second half of I94I, the moment of crisis, reveals the structure of Nazi racial thought and the priority of anti-Semitism. It was Himmler who rescued and revised an element of the initial planning, by showing Hitler how at least the final solution could be implemented: mass killing. What was consistent was Hitler's determination to eliminate Jews, a notion that always included the possibility of (although did not require) their immediate physical extermination. We are horrified by mass killing as we are not by deportation; we should be more horrified still that the Nazis found it easier to kill Jews than to deport them. Be that as it may, horror must not occlude understanding; and understanding the Holocaust requires the view from eastern Europe, the world homeland of the Jews until 1942. 